Contents List available at RAZI Publishing

Journal CleanWAS

Journal Homepage: http://www.razipublishing.com/journals/journal-cleanwas/

https://doi.org/10.26480/jcleanwas.02.2017.06.09

\title{
EFFECT OF PALM OIL MILL EFFLUENT (POME) TREATMENT BY ACTIVATED SLUDGE
}

Wee Long Wun, Gek Kee Chua*, Sim Yee Chin

Faculty of Chemical and Natural Resources Engineering University Malaysia Pahang, 26300 Kuantan, Pahang, Malaysia. *Corresponding author Email: chua@ump.edu.my

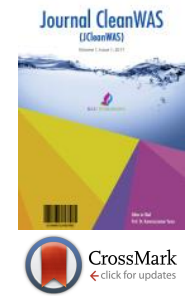

This is an open access article distributed under the Creative Commons Attribution License, which permits unrestricted use, distribution, and reproduction in any medium, provided the original work is properly cited

\section{ARTICLE DETAILS}

\section{Article History:}

Received 4 July 2017

Accepted 4 October 2017

Available online 2 November 2017

Keywords:

Palm Oil Mill Effluent Activated Sludge; Hydraulic Retention Time; Organic Loading Rate;

Mixed Liquor Volatile Suspended Solids; Solid Retention Time; Molasses; F/M Ratio.

\section{ABSTRACT}

The objective of this study is to investigate the effect of operating conditions on palm oil mill effluent (POME) using activated sludge treatment. The operating conditions examined are initial pH, hydraulic retention time (HRT), organic loading rate (OLR), initial mixed liquor volatile suspended solids (MLVSS), solid retention time (SRT), and molasses concentration added as a carbon source. The efficiency of activated sludge was evaluated by treating the anaerobic treated POME under aerobic conditions based on the F/M ratio of $0.3 \mathrm{~kg} \mathrm{BOD} / \mathrm{kg}$ MLVSS.day. The best operating condition for initial pH, HRT, OLR, initial MLVSS, SRT, and molasses concentration were found to be $6.5 \pm 0.1,48$ hours, $650 \pm 20 \mathrm{mg} / \mathrm{L}, 2000 \pm 200 \mathrm{mg} / \mathrm{L}, 10$ days and $50 \mathrm{mg} / \mathrm{L}$, respectively. However, the removal of chemical oxygen demand (COD) and biochemical oxygen demand (BOD) in POME ranging from 62 - 68\% and 60 - 65\% respectively for all best conditions. In fact, the removal of BOD still does not meet the Department of Environment (DOE)'s discharge standard limit of $20 \mathrm{mg} / \mathrm{L}$. Therefore, further investigation and study of POME treatment need to be carried out in order to find a better solution to meet the DOE discharge standard.

\section{INTRODUCTION}

A Palm oil industry is one of the very important agricultural based industries in Malaysia for the past decades. According to the statistic of Malaysian Palm Oil Board (MPOB) in year 2016, total 453 of palm oil mills in Malaysia have produced about 110.33 million tonne of Fresh Fruit Bunch (FFB) [1]. A researcher estimated that approximately $0.50-0.75$ tonnes of Palm Oil Mill Effluent (POME) will be discharged for every tonne of FFB from mill [2]. Thus, total POME discharged to the river in year 2016 was estimated in the range of 55.17 - 82.75 million tonne. According to a research paper, fresh POME which is generated by Palm Oil Mill is hot, acidic ( $\mathrm{pH}$ between 4.0 to 5.0) and brownish colloidal suspension containing high concentration of organic matter, COD $(50,000 \mathrm{mg} / \mathrm{L})$, BOD $(25,000 \mathrm{mg} / \mathrm{L})$, total suspended solids $(40,500 \mathrm{mg} / \mathrm{L})$ and oil \& grease $(4,000 \mathrm{mg} / \mathrm{L})$ [3]. Dark brownish colour of POME is probably from polymerization of tannins and low molecular weight phenolic compound [4]. Furthermore, discharge of dark brownish coloured of POME into river will inhibit the growth of aqua organism by reducing the penetration of sunlight and affect the photosynthetic activity [5].

The various of POME treatment system are currently used in Malaysia palm oil industry to comply the discharge standard limit which stated in Environmental Quality Act (EQA) 1978. However, new Palm Oil Mill need to comply with BOD $20 \mathrm{mg} / \mathrm{L}$. Ponding system is the most common one, which consist of anaerobic pond, facultative pond and aerobic pond [6,7]. To improve the performance, some palm oil mills also employ tank digesters and extended aeration (hydraulic retention time [HRT] about 40 days) [8].

Current years, activated sludge treatment was reported to improve POME treatment $[8,9,10,11]$. Another author had reported that by using activated sludge reactor after anaerobic digestion process, COD removal efficiency were found to be $83 \%$ and $57 \%$ at 36 hours and 24 hours of hydraulic retention time (HRT) respectively. Besides, a group scientist had proved that Sequencing Batch Reactor (SBR) able to achieve $82 \%$ of COD removal efficiency by maintaining the MLSS at 2,500 - 4,000 mg/L at HRT of 3 days [10]. Performance of SBR system also reported, whereby removal of COD, BOD and TSS were $96 \%, 98 \%$ and $99 \%$ with MLVSS, OLR and SLR operated in the optimum range of $17,500-20,000 \mathrm{mg} / \mathrm{L}, 1.8-$ $4.2 \mathrm{~kg} \mathrm{COD} / \mathrm{m}^{3}$ day, $0.17-0.40 \mathrm{~kg} \mathrm{BOD} / \mathrm{m}^{3}$ day and $2.5-4.6 \mathrm{~kg} \mathrm{TSS} / \mathrm{m}^{3}$ day, respectively [8].

Although many POME treatment plants have been operated successfully, majority of these palm oil mill still struggle to comply with the discharge standard under DOE regulation. Therefore, this research is to study the effect of POME treatment by activated sludge process such as initial $\mathrm{pH}$, hydraulic retention time (HRT), organic loading rate (OLR), initial mixed liquor volatile suspended solids (MLVSS), solid retention time (SRT), and molasses concentration as carbon source to obtain the optimum operating condition to comply with the regulatory standards.

\section{MATERIALS AND METHODS}

\subsection{POME sample preparation and characteristic}

Anaerobic treated POME was collected from Anaerobic Pond 4 in Neram Palm Oil Mill, Kemaman, Terengganu. The sample was stored at 4?C until the experiment. The characteristics of anaerobic treated POME collected were at a $\mathrm{pH}$ of 8.1, BOD of $658 \mathrm{mg} / \mathrm{L}$, COD of $2,450 \mathrm{mg} / \mathrm{L}$ and TSS value of $3,540 \mathrm{mg} / \mathrm{L}$ (all in average values).

\subsection{Reactor Set Up}

A 2 L conical flask completed with an aquarium pump (Model RS Electrical RS-17000, China). With air flow output of $4 \mathrm{~L} / \mathrm{min}$ and pressure of $2 \mathrm{MPa}$ was used as a bioreactor for the activated sludge process. The operating condition was based on the $\mathrm{F} / \mathrm{M}$ ratio of $0.3 \mathrm{~kg} \mathrm{BOD} / \mathrm{kg}$ MLVSS.day.

\subsection{Acclimatization of Activated Sludge}

10 liter activated sludge sample from Cargill Palm Products Sdn Bhd, Gebeng Industrial Estate, Kuantan, Pahang was acclimatized with anaerobic treated POME sample. F/M Ratio was fixed at $0.3 \mathrm{~kg} \mathrm{BOD} / \mathrm{kg}$ MLVSS.day [12]. Acclimatization was performed in a $25 \mathrm{~L}$ bioreactor tank 
completed with aeration system. The initial $\mathrm{pH}$ of POME was adjusted to the neutral $\mathrm{pH}$ range $(7.0 \pm 0.1)$ before adding to the activated sludge. The acclimatizing operation was conducted under batch mode for HRT of 24 hrs. The completion of acclimatization of activated sludge process was indicated by the removal of COD and BOD as well as MLVSS concentration reaching the constant value.

\subsection{Performance of POME treatment by Activated Sludge Process}

The experiment was conducted after transferred the acclimatized activated sludge from the bioreactor tank into $2 \mathrm{~L}$ conical flask and adding with anaerobic treated POME sample based on F/M Ratio at $0.3 \mathrm{~kg}$ BOD/kg MLVSS.day for different initial pH (4 - 10), hydraulic retention time (HRT; 12 - $144 \mathrm{hrs)}$ ), organic loading rate (OLR; $200-1000 \mathrm{mg} / \mathrm{L}$ ), initial mixed liquor volatile suspended solids (MLVSS; $1000-10000$ $\mathrm{mg} / \mathrm{L}$ ), solid retention time (SRT; 2 - 20 days), and molasses concentration as carbon source $(0-100 \mathrm{mg} / \mathrm{L})$. After each run of experiment, the activated sludge was collected for MLSS and MLVSS analysis while supernatant will be taken for $\mathrm{pH}, \mathrm{BOD}_{3}, \mathrm{COD}$ and TSS analysis.

\subsection{Analytical Methods}

All analytical determination of BOD, COD, TSS, MLSS and MLVSS were carried out in accordance with the Standard Methods for the Examination of Water and Wastewater [13]. According to the EQA 1974, BOD 3 for POME sample were analysed for 3 days incubation at 30?C. COD was measured according to Reactor Digestion Method (Method 8000) at a wavelength of $620 \mathrm{~nm}$ (APHA 5220 D) by using DRB 200 Reactor and measured by DR 890 Spectrophotometer. TSS and MLSS were measured as outlined in Standard Methods APHA 2540 D (total suspended solids dried at 103105 (2) while MLVSS were measured as outlined in Standard Methods APHA $2540 \mathrm{E}$ (volatile solids ignited at 550 [C). $\mathrm{pH}$ was measured by using pH meter (SevenEasy, Mettler Toledo, USA) and was conducted according to Standard Methods APHA 4500- $\mathrm{H}^{+}$B. DO measurement were done in accordance with the Standard Methods APHA 4500-0 G using dissolved oxygen membrane probe (Pro20, Yellow Spring Instrument, USA).

\section{RESULTS AND DISCUSSION}

\subsection{Initial pH of POME}

Initial $\mathrm{pH}$ seems to increase gradually to alkaline region, around 8.0 to 9.0 due to the precipitation of high content of available phosphate during biodegradation process of POME [14]. However, this pH range is not the optimal environmental $\mathrm{pH}$ for the healthy grow of microorganism. Thus, a suitable $\mathrm{pH}$ must be sought so that the final $\mathrm{pH}$ would comply with the discharge standard limit set by the Malaysian Department of the Environment (DOE) at pH 5.5 - 9.0.

Figure 1(a) shows that when the initial $\mathrm{pH}$ of POME is in the acidic region (pH 4.0 - 6.0), the $\mathrm{pH}$ attained after treatment is within $\mathrm{pH} 6.0$ to 7.0. Above these initial $\mathrm{pH}$ range, there was a drastic increment to the final $\mathrm{pH}$ achieved. When the initial $\mathrm{pH}$ of POME is above $\mathrm{pH} 6.5, \mathrm{pH}$ after treatment would be above $\mathrm{pH} 8$ and increased with the increment of initial ph. Hence, the ideal initial $\mathrm{pH}$ of POME seems to be $\mathrm{pH} 4$ to 6.5. The initial $\mathrm{pH}$ of POME in the acidic region $\mathrm{pH} 4.0-6.0)$ is common in anaerobic system, where the available phosphorus content will be removed in anoxic condition [15]. Thus, there is no significant increasing of $\mathrm{pH}$ at the end. However, incomplete removal of available phosphorus might lead to phosphorus carry over to facultative or aerobic system and gradually increase the POME $\mathrm{pH}[14,16,17]$.

Figure 1(a) also depicts the specific oxygen uptake rate (SOUR) of the microorganism in the POME. Generally, the SOUR achieved by the system was lower than the recommended value provided in the guidance document of the DOE. The recommended value of SOUR is above $8-20 \mathrm{mg}$ $\mathrm{O}_{2} / \mathrm{h} / \mathrm{g}$ MLVSS (Technical Guidance Document DOE-IETS-1, 2010), but at all initial $\mathrm{pH}$ of POME, the SOUR value attained was less than $5 \mathrm{mg} \mathrm{\textrm {O } _ { 2 }} / \mathrm{h} / \mathrm{g}$ MLVSS. The highest SOUR value obtained is at the initial $\mathrm{pH}$ of $6.5(4.2 \mathrm{mg}$ $\mathrm{O}_{2} / \mathrm{h} / \mathrm{g}$ MLVSS) where also reported similar result that at $\mathrm{pH} 6.59 \pm 0.05$, the microbial population had shown the highest grow rate and SOUR value indicated that the bacteria able to grow happily in the POME at the optimum $\mathrm{pH}$ of $6.5[18,19]$.

As optimum organic removal of waste water, a good treatment system should attain a MLVSS: MLSS ratio above 80 [20]. Figure 1(b) illustrates that the only system barely achieved this ratio was the one with initial $\mathrm{pH}$ of 7.0. This result disclosed that the conditions of POME are not ideal for the sustaining growth of the microorganism in which the reason behind required further investigation. Maximum BOD reduction was around $62 \%$ at initial $\mathrm{pH}$ of 7.5 . Thus, the final BOD reading after treatment was at a value of $\sim 247 \mathrm{mg} / \mathrm{L}$, which is not even met the old regulation set (< $200 \mathrm{mg} / \mathrm{L}$ ). Maximum COD reduction was at a value of $68 \%$ which occurred at initial $\mathrm{pH}$ of 7.5. Therefore, the ideal initial $\mathrm{pH}$ of POME is around $\mathrm{pH} 6.5$ to 7.5 . $\mathrm{pH} 6.5$ was chosen as the optimal for the following study because above this value, the $\mathrm{pH}$ of POME after treatment will exceed the maximum value allowed by the standard.



(a)

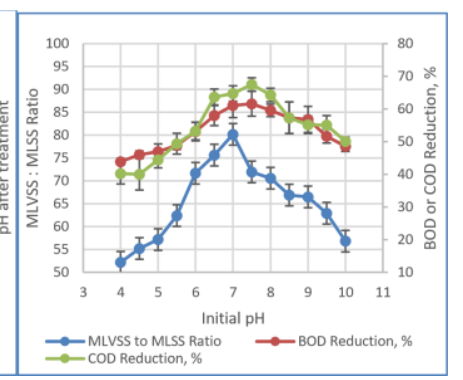

(b)
Figure1: Effect of initial pH of POME on (a) $\mathrm{pH}$ after treatment and specific oxygen uptake rate, (b) MLVSS: MLSS ratio, BOD reduction and COD reduction. Operating conditions:

HRT $=48$ hours, $\mathrm{SRT}=7$ days, MLVSS $=2,000 \pm 200 \mathrm{mg} / \mathrm{L}, \mathrm{BOD}$ initial $=$ $650 \pm 20 \mathrm{mg} / \mathrm{L}$.

\subsection{Hydraulic retention time (HRT)}

Hydraulic retention time is a key parameter to determine the period for the treatment of POME up to the required standard. Too short a period may not enough to enable a complete treatment of the waste, while too long a period is not practical for a high capacity incoming waste like POME. This is mainly due to a big land area would be required for the construction of the plant, which is a significant extra cost to the newly set up plant and a limitation to the existing plant.

Fig. 2(a) shows that when the HRT was increased from $12 \mathrm{~h}$ to $24 \mathrm{~h}$, the $\mathrm{pH}$ of POME after treatment increase from 7.3 to 8.3. Above HRT of $24 \mathrm{~h}$, the $\mathrm{pH}$ value after treatment increased insignificantly and the value is always less than $\mathrm{pH}$ 9. It can be seen that the SOUR value was still below the healthy level of $8 \mathrm{mg} \mathrm{O}_{2} / \mathrm{h} / \mathrm{g}$ MLVSS irrespective of the HRT period. The maximum SOUR occurred between 48 to $60 \mathrm{~h}$ HRT at a value of $\sim 4.6$ $\mathrm{mg} \mathrm{O}_{2} / \mathrm{h} / \mathrm{g}$ MLVSS. Above this HRT, SOUR was constant at a value of $4 \mathrm{mg}$ $\mathrm{O}_{2} / \mathrm{h} / \mathrm{g}$ MLVSS. Similarly, Fig. 2(b) depicts the ratio of MLVSS: MLSS increased when the HRT was increased and attained a maximum value around 80 at HRT between 48 to $60 \mathrm{~h}$. Further increased in the HRT causes a decreased in the MLVSS: MLSS ratio. This may be due to the depletion of nutrients when times prolong that causing the death of some of the microorganism. The maximum reduction of BOD (64\%) and COD (62\%) also occurred at HRT of $48 \mathrm{~h}$. A research also reported that at 36 hours of HRT, activated sludge process able to achieve $83 \%$ of COD removal efficiency for initial COD of POME at $1,000 \mathrm{mg} / \mathrm{L}$. Thus, the optimal HRT chosen for the following study is $48 \mathrm{~h}$.

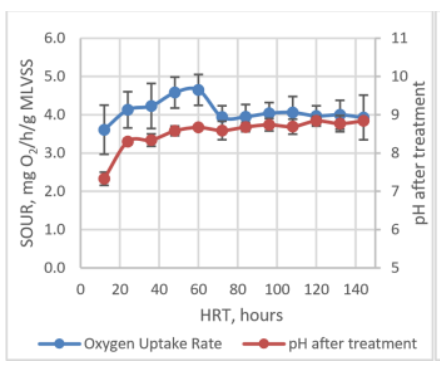

(a)



(b)
Figure 2: Effect of hydraulic retention time on the (a) pH after treatment and specific oxygen uptake rate, (b) MLVSS: MLSS ratio, BOD reduction and COD reduction. Operating conditions: $\mathrm{pH}=6.5 \pm 0.1$, SRT $=7$ days, MLVSS $=2,000 \pm 200 \mathrm{mg} / \mathrm{L}$, BOD initial $=650 \pm 20 \mathrm{mg} / \mathrm{L}$.

\subsection{Organic loading rate (OLR)}

Organic loading rate gives the indication of the susceptibility of the treatment system. It is intended to measure the amount of organic load that is able to be treated by the system. OLR is important to determine if 
this system is suitable to be used as a polishing plant and capable to treat the incoming waste up to the desired standard.

Figure 3(a) depicts that when the OLR increased from $200 \mathrm{mg} / \mathrm{L}$ to 400 $\mathrm{mg} / \mathrm{L}$, the $\mathrm{pH}$ after treatment increased from 7.2 to 8.5 . The $\mathrm{pH}$ value was fairly constant between OLR of $400 \mathrm{mg} / \mathrm{L}$ to $800 \mathrm{mg} / \mathrm{L}$. Above OLR of 800 $\mathrm{mg} / \mathrm{L}$, the $\mathrm{pH}$ after treatment increased rapidly when the OLR increased. The $\mathrm{pH}$ value exceeded the maximum allowable limit of the standard; hence, this system is not suitable to treat the POME with the incoming organic loading of more than $800 \mathrm{mg} / \mathrm{L}$. The SOUR at all the OLR values was less than $6 \mathrm{mg} \mathrm{O}_{2} / \mathrm{h} / \mathrm{g}$ MLVSS. The maximum SOUR of $5.5 \mathrm{mg} \mathrm{O}_{2} / \mathrm{h} / \mathrm{g}$ MLVSS was achieved at OLR value of $650 \mathrm{mg} / \mathrm{L}$. It is obvious that the SOUR of the system was improved as compared to the previous two sections. Nevertheless, it is still below the recommended value of $8 \mathrm{mg}$ $\mathrm{O}_{2} / \mathrm{h} / \mathrm{g}$ MLVSS. Figure 3(b) illustrates that when the OLR was increased, the MLVSS: MLSS ratio also increased. A maximum value of 80 was attained at OLR value of $600 \mathrm{mg} / \mathrm{L}$. At this value of OLR, percentage reduction of BOD and COD were $60 \%$ and $67 \%$ respectively. These were also the maximum reduction that could be achieved in this study. Based on the results obtained in this section, the OLR was fixed at a value of 650 $\mathrm{mg} / \mathrm{L}$ in the following studies.



(a)

Figure 3: Effect of organic loading rate on the (a) $\mathrm{pH}$ after treatment and specific oxygen uptake rate, (b) MLVSS: MLSS ratio, BOD reduction and COD reduction. Operating conditions: $\mathrm{pH}=6.5 \pm 0.1, \mathrm{HRT}=48 \mathrm{~h}, \mathrm{SRT}=7$ days, MLVSS $=2,000 \pm 200 \mathrm{mg} / \mathrm{L}$.

\subsection{Initial mixed liquor volatile suspended solids (MLVSS)}

Initial mixed liquor volatile suspended solids represent the amount of microorganism available to digest and treat the POME, which resemble the inoculum size in a fermentation. A sufficient amount of inoculum is required to start a fermentation and digest the organic compound in the POME to meet the discharge standard within the HRT.

Illustrated in Figure 4(a) is the $\mathrm{pH}$ after treatment, only an insignificant increased could be observed when initial MLVSS was increased from $2,000 \mathrm{mg} / \mathrm{L}$ to $10,000 \mathrm{mg} / \mathrm{L}$. The final $\mathrm{pH}$ at this range was above 8 and still within the standard limit. When the initial MLVSS was between 5,000 $\mathrm{mg} / \mathrm{L}$ to $6,000 \mathrm{mg} / \mathrm{L}$, the SOUR attained for the system was around $5.5 \mathrm{mg}$ $\mathrm{O}_{2} / \mathrm{h} / \mathrm{g}$ MLVSS, which is the maximum SOUR could be achieved by the system within the range of MLVSS studied. Unfortunately, it is still below the recommended limit. The maximum ratio of MLVSS: MLSS achieved by the system in the range of MLVSS studied was only 80 (Fig. 4(b)). This maximum ratio occurred at initial MLVSS value of 5,000 mg/L. Likewise, the maximum BOD reduction (61\%) and COD reduction (68\%) also happened at the same MLVSS value. Therefore, initial MLVSS value of $5,000 \mathrm{mg} / \mathrm{L}$ seems to be an optimal value to initiate the treatment process.

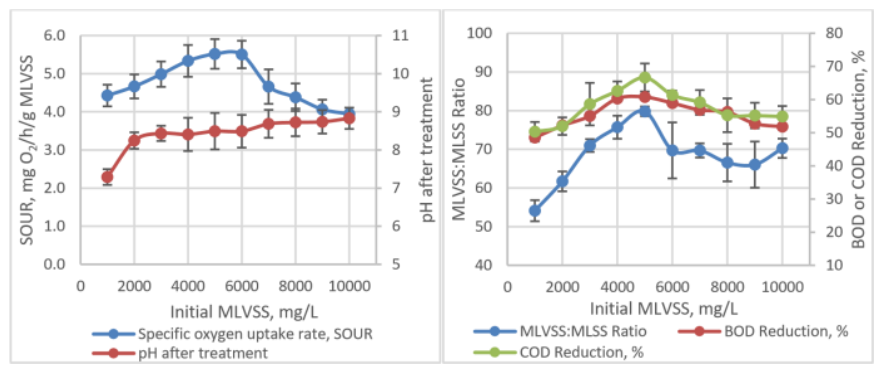

Figure 4: Effect of mixed liquor volatile suspended solid on the (a) $\mathrm{pH}$ after treatment and specific oxygen uptake rate, (b) MLVSS: MLSS ratio, BOD reduction and COD reduction. Operating conditions: $\mathrm{pH}=6.5 \pm 0.1$, HRT $=$
$48 \mathrm{~h}, \mathrm{SRT}=7$ days, BOD initial $=650 \pm 20 \mathrm{mg} / \mathrm{L}$.

Practically, it is hard to get initial MLVSS of more than 2,000 mg/L in the existing plant. A concentration step of activated sludge would be required if a higher amount of MLVSS is desired. This would indicate an extra process unit prior to the polishing plant, which also means extra cost and space. Since it is practically not feasible, the following study would still use MLVSS of 2,000 mg/L.

\subsection{Solid retention time (SRT)}

Solid retention time is the sludge age, or in other words, the amount of time the sludge remains in the reactor before it is being used as the inoculum. It determines the maturity of the sludge and the amount of active microorganism that has adapted to the environment Figure 5(a) depicts that when SRT was increased from 2 days to 6 days, the $\mathrm{pH}$ after treatment increased from 7.3 to 8.6 and remained quite constant up to SRT value of 12 days. The $\mathrm{pH}$ after treatment increased steadily if SRT was increased above 12 days. Too old a sludge seems to give some negative impact to the system. The maximum SOUR achieved was around $5.5 \mathrm{mg} \mathrm{O}_{2} / \mathrm{h} / \mathrm{g}$ MLVSS at SRT of about 10 days. Below or above this value, the SOUR values were lower, indicating a non-healthy growth of the microorganism. The maximum ratio of MLVSS: MLSS also took place at SRT of 10 days. The ratio was only around 80 (Figure 5(b)). The maximum BOD reduction was around $60 \%$ at SRT of 10 days, while the maximum COD reduction was about $67 \%$ at the same SRT value. Even though the overall performance of the system was not entirely efficient, the best SRT within the range of study was still able to be identified, which was 10 days.

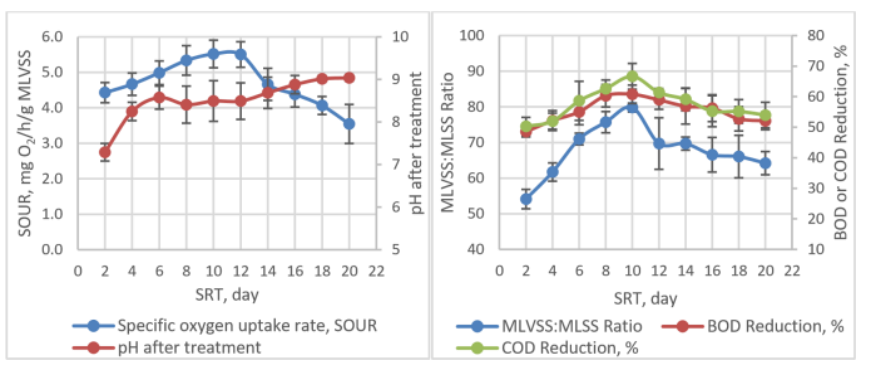

(a)

Figure 6: Effect of solid retention time on the (a) $\mathrm{pH}$ after treatment and specific oxygen uptake rate, (b) MLVSS: MLSS ratio, BOD reduction and COD reduction. Operating conditions: $\mathrm{pH}=6.5 \pm 0.1, \mathrm{HRT}=48 \mathrm{~h}, \mathrm{MLVSS}=$ $2000 \pm 200 \mathrm{mg} / \mathrm{L}$, BOD initial $=650 \pm 20 \mathrm{mg} / \mathrm{L}$.

From all the results from Section 3.1 to Section 3.5, it seems like there was some limitation in the system that retarding the growth of microorganism. The percentage reduction of BOD and COD was not changed significantly even though the operating conditions were improved. This revealed that a portion of organic compound in the POME might be non-degradable or required long time to degrade. As a result, when the degradable food has depleted, the microorganism would be starved and died. Therefore, no further BOD or COD reduction could be achieved. In addition, there might be oxygen limitation or nutrient limitation in the system as the SOUR was always at the low value which indicating unhealthy grow of the microorganism.

\subsection{Molasses concentration as external carbon source}

In view of the possible nutrient limitation, this section examined the effect of adding molasses as an external carbon source to the activated sludge system. Molasses was known to be a type of carbon source that is typically supplemented to the fermentation system [21]. As the biological treatment of POME resembling fermentation, cheap carbon source like molasses was chosen. Molasses concentration up to $100 \mathrm{mg} / \mathrm{L}$ was supplemented to the POME at the beginning of the reaction in this experiment. Other operating conditions were fixed at the optimal value obtained from the previous sections.

Figure 6(a) illustrates that addition of molasses did not affect the $\mathrm{pH}$ after treatment irrespective of the molasses concentration. The $\mathrm{pH}$ after treatment is still within the range of standard set by the DOE. When the concentration of molasses added was increased, there was an increment in the SOUR of the system. However, at molasses concentration greater than $60 \mathrm{mg} / \mathrm{L}$, the SOUR remained constant at the value of $8.3 \mathrm{mg} \mathrm{O}_{2} / \mathrm{h} / \mathrm{g}$ MLVSS. Since the higher SOUR, the healthier is the microorganism. This 
system is only barely exceeding the minimum requirement of $8 \mathrm{mg}$ $\mathrm{O}_{2} / \mathrm{h} / \mathrm{g}$ MLVSS, which indicating the vulnerability of the system. In other words, any disturbance would easily upset the system. Figure 6(b) shows that once the molasses concentration fed exceeded $50 \mathrm{mg} / \mathrm{L}$, the MLVSS: MLSS ratio would be more than 80 . Nevertheless, differences in the ratio was not significant. Correspondingly, the percentage reduction of BOD and COD was not showing substantial changed around the value of $65 \%$. This mean that addition of molasses did not aid in the treatment of POME even though it facilitates the healthy grow of the microorganism. Molasses, as a degradable organic component, was only functioned as the food to the microorganism, thus improved the SOUR and support the growth of the microorganism. Other organic components in the POME, however, were non-degradable or slow degradable. Consequently, there was no further reduction of BOD or COD could be observed in the time frame and operating conditions employed in this study. To confirm the postulation of the existing of slow or non-degradable organic compound, further investigation was required.



(a)



(b)
Figure 6: Effect of external carbon source concentration on the (a) $\mathrm{pH}$ after treatment and specific oxygen uptake rate, (b) MLVSS: MLSS ratio, $\mathrm{BOD}$ reduction and COD reduction. Operating conditions: $\mathrm{pH}=6.5 \pm 0.1$, $\mathrm{HRT}=48 \mathrm{~h}, \mathrm{SRT}=10$ days, $\mathrm{MLVSS}=2000 \pm 200 \mathrm{mg} / \mathrm{L}, \mathrm{BOD}$ initial $=650 \pm$ $20 \mathrm{mg} / \mathrm{L}$.

\section{CONCLUSION}

It can be concluded that activated sludge treatment process able to remove the organic matter in POME, where the removal of COD and BOD in POME are in the range of $62-68 \%$ and $60-65 \%$ respectively, for all the best conditions tested. The optimum condition for activated sludge process obtained were initial $\mathrm{pH}=6.5 \pm 0.1, \mathrm{HRT}=48 \mathrm{hrs}$, SRT $=10$ days, MLVSS $=2000 \mathrm{mg} / \mathrm{L}, \mathrm{BOD}$ initial $=650 \mathrm{mg} / \mathrm{L}$ and molasses concentration $=50 \mathrm{mg} / \mathrm{L}$. The result obtained in this study are very important and useful either in designing the new POME treatment plant by using activated sludge system or operation of existing activated sludge system in POME treatment plant. However, activated sludge treatment process unable to remove the BOD until below $20 \mathrm{mg} / \mathrm{L}$, following DOE's new discharge standard. Therefore, further investigation and study of POME treatment need to be carried out, which does not limit to the activated sludge system, for example kinetic study of activated sludge process in POME treatment and characteristic of POME (COD content and polyaromatic hydrocarbon content), which play very important role in POME treatment system.

\section{REFERENCES}

[1] MPOB, Malaysia Palm Oil Board. 2016. Home page: http://www.mpob.gov.my.

[2] Yacob, S., Hassan, M.A., Shirai, Y., Wakisaka, M., and Subahs, S. 2005. Baseline study of methane emission from open digesting tanks of palm oil mill effluent treatment. Chemosphere, 59 (11), 1575-1581.

[3] Ma, A.N. 2000. Environmental Management for the Oil Palm Industry. Palm Oil Dev., 30,110.

[4] Limkhuansuwan, V., and Chaiprasert, P. 2010. Decolorization of molasses melanoidins \& Palm Oil Mill Effluent phenolic compound by fermentative lactic acid bacteria. Journal of Environmental Science, 22 (8), 1209-1217.

[5] Neoh, C.H., Yahya, A., Adnan, R., Abdul Majid, Z., and Ibrahim, Z. 2013. Optimization of decolorization of Palm Oil Mill Effluent (POME) by growing cultures of Aspergillus fumigates using response surface methodology. Environmental Science Pollution Research, 20 (5), 291223.

[6] Wong, K.K. 1980. Application of Ponding Systems in the Treatment of Palm Oil Mill and Rubber Mill Effluents. Pertanika, 3 (2), 133-141.

[7] Chin, K.K., Lee, S.W. and Mohammad, H.H. 1996. A study of palm oil mill effluent treatment using pond system. Water Science \& Technology, 34 (11), 119-123.

[8] Chan, Y.J., Chong, M.F., and Law, C.L. 2010. Biological treatment of anaerobically digested palm oil mill effluent (POME) using a Lab-Scale Sequencing Batch Reactor (SBR). Journal of Environmental Management, 91 (8), 1738 - 1746.

[9] Vijayaraghavan, K., Ahmad, D., Ezani Bin Abdul Aziz, M. 2007. Aerobic treatment of palm oil mill effluent. Journal of Environmental Management, 82 (2), 24-31.

[10] Fun, C.W., Haq, M.R.U., and Kutty, S.R.M. 2007. Treatment of palm oil mill effluent using biological sequencing batch reactor system. WIT Transactions on Ecology and the Environment, 104.

[11] Gobi, K., Mashitah, M.D., Vadivelu, V.M. 2011. Development and utilization of aerobic granules for the palm oil mill (POM) wastewater treatment. Chemicals Engineering Journal, 174 (1), 213-220.

[12] Department of Environment Malaysia, 2010. Guidance Document on the Design and Operation of Industrial Effluent Treatment Systems, Specified in Regulation 5, Environmental Quality (Industrial Effluent) Regulation 2009. $2^{\text {nd }}$ Edition. Department of Environment Malaysia.

[13] APHA, 1989. Standard Methods for the Examination of Water and Wastewater, $20^{\text {th }}$ ed. Washington D.C, USA: American Public Health Association.

[14] Huan, K.L. 1987. Trials on long-term effects of application of POME on soil properties, oil palm nutrition and yields. In: Proceedings of the International Oil Palm, Palm Oil Conferences (eds.) Dr. B. Hj. Abdul Halim, Hassan Chew Poh Soon, B.J. Woond, Dr. E. PushParajah (eds.) 2, 575-598.

[15] Yamashita T., and Ikemoto R.Y. 2014. Nitrogen and Phosphorus Removal from Wastewater Treatment Plant Effluent via Bacterial Sulphate Reduction in an Anoxic Bioreactor Packed with Wood and Iron. International Journal of Environmental Research and Public Health, 11 (9), 9835-9853.

[16] Okwute, L. O., and Isu, N. R. 2007. The Environmental Impact of Palm Oil Mill Effluent (POME) on some physicochemical parameters and total aerobic bio load of soil at a dump site in Anyigba, Kogi State, Nigeria. African Journal of Agricultural Research, 2 (12), 656 - 662.

[17] Eze, V.C., Owunna, N. D., and Avoaja, D.A. 2013. Microbiological and Physicochemical Characteristics of Soil Receiving Palm Oil Mill Effluent in Umuahia, Abia State, Nigeria. Journal of Natural Sciences Research, 3 (1), 20-24.

[18] Ohimain, E.I., Izah, S.C., and Jenakumo, N. 2013. Physicochemical and microbial screening of palm oil mill effluents for amylase production. Greener Journal of Biological Sciences, 3 (8), 307-318.

[19] Zielinska, M., Bernat K., Cydzik-Kwiatkowska, A., and WoinowskaBaryla, I. 2012. Respirometric Activity of Activated Sludge in Sequencing Batch Reactor Depending on Substrate and Dissolved Oxygen Concentration. Environmental Protection Engineering, 38 (2), 42-49.

[20] Harun, H., Nor-Anuar., A. 2014. Development and Utilization of Aerobic Granules for Soy Sauce Wastewater Treatment: Optimization by Response Surface Methodology. Jurnal Teknologi, 69 (5), 31-37.

[21] Technical Guidance Document Series Number: DOE-IETS-1, 2010. Guidance Document on Performance Monitoring of Industrial Effluent Treatment System Specified in Regulation 9(a) Environmental Quality (Industrial Effluent) Regulation 2009. Third Edition. Page 19. 